Jurnal Perikanan (2019) Volume 9. No. 1 : 93-100

DOI : https://doi.org/10.29303/jp.v8i2.145

\title{
PERTUMBUHAN RUMPUT LAUT (Kappaphycus alvarezii) \\ HASIL KULTUR JARINGAN YANG DITANAM DENGAN BERAT BIBIT YANG BERBEDA
}

\section{THE GROWTH OF SEAWEED (Kappaphycus alvarezii) FROM TISSUE CULTURE CULTIVATED WITH DIFFERENT SEEDLING WEIGHT}

\author{
Baiq Sri Ismariani $^{1)}$, Aluh Nikmatullah ${ }^{2)}$, Nunik Cokrowati ${ }^{1 *}$, \\ ${ }^{1)}$ Program Studi Budidaya Perairan, Universitas Mataram \\ ${ }^{2)}$ Program Studi Agroekotenologi Fakultas Pertanian \\ Jl. Pendididkan No. 37 Mataram, NTB
}

\begin{abstract}
Abstrak
Penelitian ini bertujuan untuk mengetahui pengaruh berat bibit kultur jaringan yang berbeda terhadap pertumbuhan rumput laut Kappaphycus alvarezii dan untuk mengetahui berat bibit hasil kultur jaringan yang optimal untuk pertumbuhan rumput laut jenis Kappaphycus alvarezii. Penelitian ini menggunakan Rancangan Acak Lengkap (RAL) yang terdiri atas 4 perlakuan menggunakan bibit hasil kultur jaringan dengan perbedaan berat bibitnya. Perlakuan tersebut adalah P1 : bibit dengan berat 50 gr, P2 : bibit dengan berat 75 gr, P3 : bibit dengan berat 100 gr, P4 : bibit dengan berat 125 gr. Perlakuan diulang sebanyak 4 kali (4 rakit). Data variabel penelitian ditabulasi menggunakan mikrosof excel dan dianalisis menggunakan analisis sidik ragam (ANOVA) pada taraf nyata 5\%, kemudian dilakukan uji lanjut dengan uji Least Significant Difference (LSD). Hasil penelitian ini adalah pertambahan berat tertinggi didapat pada bibit 125 gr dan laju pertumbuhan tertinggi pada bibit 50 gr. Setiap perlakuan berpengaruh terhadap pertumbuhan Kappaphycus alvarezii. Kesimpulan penelitian ini adalah perbedaan berat bibit rumput laut Kappaphycus alvarezii berpengaruh terhadap pertumbuhan mutlak dan laju pertumbuhan spesifik. Laju pertumbuhan rumput laut paling tinggi didapat pada berat bibit 50 gr. Hasil persentase pertambahan beratnya yaitu berat 50 gr mencapai $622 \%$ atau 6,22 kali dari bobot awal tubuhnya sedangkan pada berat 125 gr hanya mencapai 407\% atau 4,07 kali dari bobot awal tubuhnya.
\end{abstract}

Kata kunci : Kappaphycus alvarezii, pertumbuhan, berat, bibit, fotosintesis.

\begin{abstract}
This study aimed to determine the effect of the weight of different tissue culture seedlings on the growth of seaweed (Kappaphycus alvarezii) and to determine the weight of seedlings from tissue culture optimal for the growth of Kappaphycus alvarezii. This study used a Completely Randomized Design (CRD) consisting of 4 treatments using tissue culture seedlings with different seed weight. The treatment consisted of P1: seeds weighing 50 gr, P2: seeds weighing 75 gr, P3: seeds weighing 100 gr, and P4: seeds weighing 125 gr. Each treatment was repeated 4 times (using 4 rafts). Data from the research variables obtained were tabulated using microsoft excel and analyzed using analysis of variance (ANOVA) at 5\% of significance level,

*Korespondensi :

Email: nunikcokrowati@unram.ac.id
\end{abstract}


then further testing was carried out using Least Significant Difference (LSD) test. The highest weight of seaweed was obtained from P4 (125 gr of seedling weight) and the highest growth found in P1 (50 gr of seedling weight). According to data analysis, each treatment had significant effect $(\mathrm{p}<0.05)$ on seaweed growth. This is related to the competition experienced by individual seaweed in absorbing sunlight for photosynthesis. Seed weight is one of the technical factors that can affect the growth of seaweed. In addition, density of seaweed in each bond needs to be considered because seaweed which is too dense can cause the seaweed to fall out.

Keywords: Kappaphycus alvarezii, growth, weight, seeds, photosynthesis.

\section{Pendahuluan}

Rumput laut merupakan tanaman makro alga dan termasuk dalam divisi Thallophyta (tumbuhan bertallus), yaitu dari segi morfologi rumput laut tidak memperlihatkan adanya perbedaan yang jelas antara akar, batang dan daun dimana bagian tersebut biasa disebut dengan thallus (Purwanto, 2008).

Rumput laut di perairan Indonesia terdiri dari 555 genus, dimana 55 genus diketahui mempunyai nilai ekonomis yang tinggi, termasuk Kappaphycus sp. Eucheuma sp. Gracilaria sp. Gelidium sp. dan Sargassum sp. Pada saat ini kebutuhan dunia akan rumput laut genus Kappaphycus sp. adalah sepuluh kali lipat dari persediaan alaminya yang ada di dunia. Indonesia dan Philipina merupakan dua negara penyuplai terbesar bahan baku rumput laut bagi negara-negara yang membutuhkan. Meningkatnya permintaan akan bahan baku rumput laut disebabkan oleh meningkatnya kebutuhan industri seperti industri makanan, farmasi, kedokteran dan kosmetika. Rumput laut mengandung sumber hidrokoloid seperti alginat, karagenan dan agar yang sangat dibutuhkan oleh berbagai macam industri (Ditjenkan Budidaya, 2004). Baweja (2016) menjelaskan bahwa Kappaphycus alvarezii merupakan alga merah yang penting dan dapat digunakan sebagai bahan baku makanan, obat dan kosmetika.

Faktor penting yang menentukan keberhasilan usaha budidaya rumput laut adalah penggunaan bibit yang memiliki kualitas baik, yaitu bibit yang dapat tumbuh dengan cepat dan memiliki cabang yang banyak serta bebas dari serangan penyakit. Bibit rumput laut yang digunakan secara terus menerus akan mengalami penurunan kualitas hidupnya, alternatif untuk mengatasi kendala tersebut yakni dengan menggunakan bibit berkualitas yang dihasilkan melalui Kultur Jaringan. Anas dkk (2018) menjelaskan bahwa kualitas bibit dapat mempengaruhi pertumbuhan rumput laut. Pada proses produksi bibit rumput laut melalui kultur jaringan, bibit kultur jaringan diaklimatisasi kemudian diregenerasikan untuk memperbanyak jumlah bibit kemudian disebarkan ke pembudidaya setelah diregenerasikan 10 kali (F10). Bibit hasil kultur jaringan dan bibit bukan hasil kultur jaringan di lapangan akan berbeda pertumbuhannya. Oleh karena itu, regenerasi stok bibit (F5 sampai F10) diduga memerlukan teknik pembibitan yang berbeda (Sarifin, 2012). Menurut Maryunus (2017) menjelaskan bahwa bibit rumput laut hasil kultur jaringan, lebih tahan terhadap serangan penyakit dan perubahan kondisi lingkungan.

Pada proses penanaman rumput laut, faktor penting yang harus dipertimbangkan yaitu jumlah bibit yang tepat agar rumput laut dapat tumbuh dengan optimal. Oleh karena itu perlunya dilakukan penelitian ini adalah untuk mengetahui pengaruh berat bibit hasil kultur jaringan yang berbeda 
terhadap pertumbuhan rumput laut Kappaphycus alvarezii.

\section{Metode Penelitian}

\section{Waktu dan Tempat Penelitian}

Penelitian ini dilaksanakan pada Februari sampai dengan April tahun 2015, di Seaweeds Center Balai Perikanan Budidaya Laut (BPBL) Lombok Gerupuk, Kecamatan Pujut, Kabupaten Lombok Tengah, Provinsi Nusa Tenggara Barat. Pengujian sampel Rumput Laut dan Uji kualitas Air dilaksanakan di Laboratorium Kesehatan Ikan dan Lingkungan (KESLING) di Balai Perikanan Budidaya Laut (BPBL) Lombok Sekotong, Kecamatan Sekotong Barat, Kabupaten Lombok Barat, Provinsi Nusa Tenggara Barat.

\section{Rancangan Percobaan}

Penelitian menggunakan Rancangan Acak Lengkap (RAL) yang terdiri dari 4 perlakuan yaitu P1 : bibit kultur jaringan dengan berat bibit 50 gr; P2 ; bibit kultur jaringan dengan berat bibit 75 gr ; P3 : bibit kultur jaringan dengan berat bibit 100 gr; P4 : bibit kultur jaringan dengan berat bibit 125 gr. Masing-masing perlakuan diulang sebanyak 4 kali (4 rakit), sehingga diperoleh satu unit eksperimen dengan 20 unit percobaan.

\section{Tahap Persiapan Rakit}

\section{Pelaksanaan Penelitian}

Rakit apung dibuat dari paralon PVC dengan diameter 1 inci dengan ukuran panjang 2,5 $\mathrm{m}$ dan lebar 2,5 $\mathrm{m}$. Rakit apung paralon diikatkan kedalam rakit bambu yang berukuran $8 \times 12 \mathrm{~m}$. Pada rakit paralon terdapat tali ris (tali polietilen dengan diameter $4 \mathrm{~mm}$ ) dengan jarak antar tali 50 $\mathrm{cm}$. Rakit apung diletakkan secara berjajar di perairan.

\section{Tahap Persiapan Bibit Rumput Laut}

Bibit rumput laut yang digunakan adalah bibit hasil kultur jaringan yang telah diperbanyak oleh BPBL dan bibit bukan hasil kultur jaringan yang diperoleh dari pembudidaya. Bibit rumput laut ditimbang dengan berat bibit awal sesuai dengan perlakuan yaitu dengan berat $50 \mathrm{gr}, 75 \mathrm{gr}$, 100 gr dan 125 gr. Bibit kemudian diikatkan pada tali ris menggunakan tali rafia dengan jarak antar bibit yaitu $25 \mathrm{~cm}$. Jarak antar tali ris adlah $50 \mathrm{~cm}$ dan tali ris diletakkan secara acak di setiap rakit apung.

\section{Pengukuran Laju Pertumbuhan Rumput Laut}

Pertumbuhan mutlak rumput laut diamati dari awal hingga akhir kegiatan penelitian. Menurut Effendi (2003), pertumbuhan mutlak diukur menggunakan rumus pertumbuhan mutlak yaitu dengan rumus $: G=W_{t}-W_{0}, \quad(\mathrm{G}=$ Pertumbuhan Mutlak Rata-Rata (\%)), $\left(\mathrm{W}_{t}=\right.$ Berat Bibit Pada Akhir Penelitian (gr) $),\left(\mathrm{W}_{0}=\right.$ Berat Bibit Pada Awal Penelitian (gr)).

Laju Pertumbuhan Spesifik (LPS) diperoleh dengan menimbang bibit basah rumput laut setiap 1 kali seminggu selama 30 hari. Menurut Dawes (1994), untuk menghitung Laju Pertumbuhan Spesifik digunakan turunan dari persamaan Huisman yaitu dengan rumus :

$L P S=\ln \mathrm{Wt} / \mathrm{t}-\ln \mathrm{Wo} / \mathrm{t} \times 100 \%$, (LPS $=$ Laju Pertumbuhan Spesifik rata-rata $(\%)),\left(\mathrm{W}_{t}=\right.$ Berat rata-rata bibit pada ti $(\mathrm{g})(\mathrm{I}$ $=$ minggu $\mathrm{I}$, minggu II...t $))\left(\mathrm{W}_{0}=\right.$ Berat rata-rata bibit pada $\mathrm{ti}-1(\mathrm{~g}) ; \mathrm{t}=$ Periode Pengamatan (hari)).

\section{Pengamatan Insiden Hama dan Penyakit}

Pengamatan hama dan penyakit pada rumput laut Kappaphycus alvarezii dilakukan secara visual pada saat dilakukan penimbangan rumput laut.

\section{Pengukuran Kualitas Air}


Parameter kualitas air yang diamati adalah suhu, salinitas, $\mathrm{pH}, \mathrm{DO}, \mathrm{COD}$, amonia (NH3-N), Nitrat (NO3-N), Fospat (PO4-P), kecerahan, kecepatan Arus.

\section{Penentuan Sampel}

Penentuan sampel yang diamati diambil secara acak pada awal kegiatan penelitian sebanyak $30 \%$ dari masingmasing tali ris kemudian ditandai untuk diamati pertumbuhan dan insiden penyakit disetiap minggu.

\section{Cara Pengamatan}

Pengamatan parameter pertumbuhan, insiden penyakit dan uji kualitas air dilakukan setiap minggu selama 45 hari. Penimbangan berat rumput laut dilakukan dengan menimbang rumput laut menggunakan timbangan analitik. Pengamatan hama dan penyakit dilakukan bersamaan pada saat penimbangan rumput laut. Uji kualitas air dilakukan dengan mengambil sampel air setiap minggu kemudian dianalisa di Laboratorium KESLING di BPBL Sekotong.

\section{Analisis Data}

Data dianalisa menggunakan Analysis of Variance (ANOVA), apabila terdapat pengaruh yang signifikan (berbeda nyata) dari setiap perlakuan maka diuji lanjut menggunakan uji lanjut BNT (Beda Nyata Terkecil) atau LSD (Least Significant Difference).

\section{Hasil Penelitian}

Berdasarkan hasil Analysis of Variance (ANOVA), diketahui bahwa perbedaan berat bibit berpengaruh $(p<0.05)$ terhadap pertumbuhan mutlak rumput laut. Pengaruh berat bibit yang berbeda terhadap pertumbuhan mutlak rumput laut (Kappaphycus alvarezii) setiap minggunya dapat dilihat pada Tabel 1. Perbedaan laju pertumbuhan dan pertambahan berat rumput laut diketahui dengan melakukan analisa regresi.

Tabel 1. Pertumbuhan mutlak rumput laut (Kappaphycus alvarezii) hasil kultur jaringan disetiap minggunya yang dipengaruhi oleh berat bibit yang berbeda.

\begin{tabular}{lllll}
\hline Perlakuan & \multicolumn{4}{c}{ Pertumbuhan Mutlak (gr) } \\
\cline { 2 - 5 } & Minggu & Minggu & Minggu & Minggu \\
& ke-1 & ke-2 & ke-3 & ke-4 \\
Berat 50 gr & $65,35^{\mathrm{a}}$ & $64,50^{\mathrm{a}}$ & $60,77^{\mathrm{a}}$ & $70,27^{\mathrm{a}}$ \\
Berat 75 gr & $72,77^{\mathrm{b}}$ & $70,47^{\mathrm{b}}$ & $74,50^{\mathrm{b}}$ & $81,67^{\mathrm{b}}$ \\
Berat 100 gr $^{\mathrm{c}}$ & $81,85^{\mathrm{c}}$ & $84,92^{\mathrm{c}}$ & $80,67^{\mathrm{b}}$ & $87,90^{\mathrm{c}}$ \\
Berat 125 gr & $95,00^{\mathrm{d}}$ & $98,90^{\mathrm{d}}$ & $93,82^{\mathrm{c}}$ & $96,42^{\mathrm{d}}$ \\
(LSD 0,05) & 4,98 & 5,33 & 6,38 & 6,15 \\
\hline
\end{tabular}

Pengaruh berat bibit yang berbeda terhadap laju pertumbuhan spesifik rumput laut (Kappaphycus alvarezii) setiap minggunya dapat dilihat pada Tabel 2 .

Tabel 2. Laju pertumbuhan spesifik rumput laut (Kappaphycus alvarezii) disetiap minggunya dengan berat bibit yang berbeda.

\begin{tabular}{|c|c|c|c|c|}
\hline \multirow[t]{2}{*}{ Perlakuan } & \multicolumn{4}{|c|}{ Pertumbuhan Spesifik (\%)/hari } \\
\hline & $\begin{array}{l}\text { Minggu } \\
\text { ke-1 }\end{array}$ & $\begin{array}{l}\text { Minggu } \\
\text { ke-2 }\end{array}$ & $\begin{array}{l}\text { Minggu } \\
\text { ke-3 }\end{array}$ & $\begin{array}{l}\text { Minggu } \\
\text { ke-4 }\end{array}$ \\
\hline Berat $50 \mathrm{gr}$ & $11,93^{\mathrm{c}}$ & $6,35^{b}$ & $4,15^{b}$ & $3,66^{\mathrm{b}}$ \\
\hline Berat 75 gr & $9,68^{b}$ & $5,57^{\mathrm{a}}$ & $4,19^{b}$ & $3,51^{\mathrm{b}}$ \\
\hline Berat $100 \mathrm{gr}$ & $8,54^{\mathrm{a}}$ & $5,47^{\mathrm{a}}$ & $3,77^{\mathrm{a}}$ & $3,22^{\mathrm{a}}$ \\
\hline Berat $125 \mathrm{gr}$ & $8,07^{\mathrm{a}}$ & $5,30^{\mathrm{a}}$ & $3,68^{\mathrm{a}}$ & $3,01^{\mathrm{a}}$ \\
\hline$(\mathrm{LSD} 0,05)$ & 0,43 & 0,39 & 0,34 & 0,36 \\
\hline
\end{tabular}

Pada Tabel tersebut dapat diketahui bahwa Laju Pertumbuhan spesifik rumput laut berbanding terbalik dengan laju pertumbuhanya. Laju pertumbuhan tertinggi pada perlakuan 50 gr yaitu $3-11 \%$ sedangkan yang terendah pada berat $125 \mathrm{gr}$ yaitu $3-8 \%$. Pengaruh berat bibit yang berbeda terhadap pertumbuhan rumput laut dapat dilihat pada Tabel 3. Pada penelitian ini juga dilakukan pengamatan kualitas air sebagaimana pada tabel 4 . 
Tabel 3. Persentase pertambahan berat rumput laut (Kappaphycus alvarezii) hasil kultur jaringan disetiap minggunya yang dipengaruhi oleh berat bibit yang berbeda.

\begin{tabular}{lllll}
\hline Perlakuan & \multicolumn{3}{l}{$\begin{array}{l}\text { Persentase Pertumbuhan Rumput } \\
\text { Laut (\%) }\end{array}$} \\
\cline { 2 - 5 } & $\begin{array}{l}\text { Minggu } \\
\text { ke-1 }\end{array}$ & $\begin{array}{l}\text { Minggu } \\
\text { ke-2 }\end{array}$ & $\begin{array}{l}\text { Minggu } \\
\text { ke-3 }\end{array}$ & $\begin{array}{l}\text { Minggu } \\
\text { ke-4 }\end{array}$ \\
Berat 50 gr & 231 & 360 & 481 & 622 \\
Berat 75 gr & 197 & 291 & 390 & 499 \\
Berat 100 gr & 182 & 267 & 347 & 435 \\
Berat 125 gr & 176 & 255 & 330 & 407 \\
\hline
\end{tabular}

Tabel 4. Hasil pengukuran kualitas air bibit rumput laut (Kappaphycus alvarezii) hasil kultur jaringan

\begin{tabular}{lllll}
\hline Parameter & $\begin{array}{l}\text { Minggu } \\
\text { Ke-1 }\end{array}$ & $\begin{array}{l}\text { Minggu } \\
\text { Ke-2 }\end{array}$ & $\begin{array}{l}\text { Minggu } \\
\text { Ke-3 }\end{array}$ & $\begin{array}{l}\text { Minggu } \\
\text { Ke-4 }\end{array}$ \\
\hline Suhu & $28^{\circ} \mathrm{C}$ & $29^{\circ} \mathrm{C}$ & $26^{\circ} \mathrm{C}$ & $26^{\circ} \mathrm{C}$ \\
Salinitas & $34 \mathrm{ppt}$ & $32 \mathrm{ppt}$ & $34 \mathrm{ppt}$ & $35 \mathrm{ppt}$ \\
$\mathrm{pH}$ & 6,7 & 6,8 & 6,8 & 7,1 \\
$\mathrm{DO}$ & $6,6 \mathrm{mg} / 1$ & 4,65 & $5,2 \mathrm{mg} / 1$ & 4,28 \\
& & $\mathrm{mg} / 1$ & & $\mathrm{mg} / 1$ \\
$\mathrm{COD}$ & $1 \mathrm{mg} / 1$ & $1 \mathrm{mg} / 1$ & $2 \mathrm{mg} / 1$ & $1 \mathrm{mg} / 1$ \\
$\mathrm{PO} 4-\mathrm{P}$ & 2,06 & 2,06 & $<0,05$ & $<0,05$ \\
& $\mathrm{mg} / 1$ & $\mathrm{mg} / 1$ & $\mathrm{mg} / 1$ & $\mathrm{mg} / 1$ \\
$\mathrm{NO} 3-\mathrm{N}$ & $0,5 \mathrm{mg} / 1$ & $1,2 \mathrm{mg} / 1$ & $0,5 \mathrm{mg} / 1$ & $0,5 \mathrm{mg} / 1$ \\
$\mathrm{NH} 3-\mathrm{N}$ & 0,001 & 0,005 & 0,001 & 0,007 \\
& $\mathrm{mg} / 1$ & $\mathrm{mg} / 1$ & $\mathrm{mg} / 1$ & $\mathrm{mg} / 1$ \\
\hline
\end{tabular}

\section{Pembahasan}

Pertumbuhan didefinisikan sebagai pertambahan atau perubahan ukuran suatu makhluk hidup atau organisme, dapat berupa berat atau panjang dan tinggi dalam jangka waktu tertentu yang disebabkan karena pembelahan sel dan pertambahan massa sel (Dawes, 1994). Pertumbuhan menurut Bhakuni, D.S. and D.S. Ranat. (2005) dapat diartikan sebagai perubahan ukuran suatu organisme yang dapat berupa berat atau panjang dalam waktu tertentu.

Pertumbuhan rumput laut Kappaphycus alvarezii dipengaruhi oleh dua faktor yaitu faktor eksternal dan faktor internal. Faktor internal yang berpengaruh terhadap pertumbuhan rumput laut ini antara lain jenis, galur, bagian thallus dan umur thallus yang digunakan sebagai bibit, sedangkan faktor eksternal yang berpengaruh antara lain keadaan lingkungan fisik dan kimiawi perairan. Namun demikian selain faktorfaktor tersebut, ada faktor lain yaitu faktor pengelolaan yang dilakukan oleh manusia. Faktor pengelolaan oleh manusia dalam kegiatan rumput laut kadang merupakan faktor utama yang harus diperhatikan seperti substrat perairan dan juga penggunaan berat bibit yang optimal dalam satu rakit apung (Prihaningrum, 2001). Lobban,C.and Paul, J.H. (2000) menjelaskan bahwa faktor-faktor yang mempengaruhi pertumbuhan rumput laut adalah usia, fenotip, genotip, kondisi reproduksi dan nutrisi yang ada di perairan.

Perbedaan berat bibit berpengaruh terhadap pertumbuhan rumput laut (Kappaphycus alvarezii). Hal ini berkaitan dengan persaingan dalam menyerap cahaya matahari. Berat bibit merupakan faktor teknis yang dapat berpengaruh terhadap pertumbuhan rumput laut. Jumlah kepadatan disetiap ikatan rumput laut perlu diperhatikan agar tidak terlalu padat sehingga dapat menyebabkan rumput laut rontok. Jika kepadatan dalam satu rumpun rumput laut tinggi maka cahaya matahari yang masuk ke air akan sulit diserap oleh bagian rumput laut. Penggunaan berat bibit yang berbeda pada penelitian ini berpengaruh terhadap pertumbuhan rumput laut, karena berat bibit mempengaruhi pertambahan berat dan laju pertumbuhan rumput laut.

Bibit yang digunakan merupakan bagian thallus yang muda dan memiliki banyak cabang thallus. Sehingga semakin besar jumlah bibit yang digunakan maka semakin banyak bagian thallus yang menyerap nutrisi dan cahaya matahari. Hal itu akan mengakibatkan semakin banyak bagian 
thallus yang melakukam fotosintesis. Doty (1987), mengemukakan bahwa rumput laut merupakan tumbuhan laut yang mempunyai derivat klorofil sehingga memerlukan sinar matahari untuk kelangsungan hidupnya. Sintesis klorofil sangat dipengaruhi oleh cahaya. Apabila tanaman disinari dengan cahaya yang cukup maka pembentukan klorofil akan lebih sempurna. Menurut Dwijoseputro (1989), pembentukan klorofil dimulai dari protoklorofil yang mengalami reduksi menjadi klorofil- $a$ apabila ada sinar matahari. Sinar matahari diserap oleh protoklorofil dan dirubah menjadi klorofil- $a$. Sehingga jika dalam satu rumpun rumput laut terlalu bergerombol maka bagian yang tertutupi oleh thallus yang lain akan sulit menetrasi cahaya matahari yang masuk sehingga tidak dapat melakukan fotosintesis secara maksimal.

Thallus yang semakin banyak akan mengakibatkan energi yang akan dibutuhkan semakin besar. Energi tersebut akan digunakan oleh rumput laut untuk tumbuh, beradaptasi dengan lingkungannya dan menyembuhkan luka pada bagian thallusnya. Rumput laut merupakan tumbuhan yang akan tetap mengalami pertumbuhan selama keadaan lingkungannya yang tetap optimal dan mencukupi bagi unsur hara yang diperlukan. Proses fotosintesis akan menghasilkan karbohidrat sebagai bahan makan rumput laut untuk memperoleh energi berupa ATP, dimana energi tersebut akan digunakan untuk respirasi. Menurut Abidin (1987), keberhasilan cahaya yang diserap oleh tanaman tergantung pada intensitasnya. Eucheuma yang ditanam di permukaan perairan akan mendapat penyinaran yang lebih lama, dibanding dengan yang ditanam di perairan yang lebih dalam. Adanya perbedaan intensitas cahaya dan lama penyinaran terhadap alga diduga akan mempengaruhi pembentukan klorofil, sehingga klorofil di kedalaman $20 \mathrm{~cm}$ lebih banyak jumlahnya daripada di kedalaman $70 \mathrm{~cm}, 120 \mathrm{~cm}$ dan 170 cm (Veronika dan Munifatul Izzati, 2013).

Keadaan lingkungan yang kurang optimal dapat menyebabkan pertumbuhan rumput laut menjadi menurun bahkan bisa tidak mengalami pertumbuhan, hal tersebut dapat dipengaruhi oleh ombak dan pasang surut air laut, kecepatan arus, intensitas penyinaran matahari, kecerahan dan kandungan unsur hara yang terdapat di perairan. Hal ini sesuai dengan pendapat Aslan (1998), yang mengatakan bahwa umumnya Kappaphycus alvarezii tumbuh dengan baik di daerah pantai terumbu. Habitat khasnya adalah daerah yang memperoleh aliran air laut yang tetap, variasi suhu harian yang kecil dan substrat batu karang mati. Hal ini diperkuat juga oleh pendapat Cokrowati (2013), yang mengemukakan bahwa dalam pemilihan lokasi budidaya rumput laut perlu memperhatikan kuat arus perairannya. Kuat arus berperan penting dalam budidaya Kappaphycus alvarezii karena arus yang baik akan membawa nutrisi bagi tanaman, karena rumput laut akan bersih dari kotoran maupun endapan yang menempel akan hanyut oleh arus. Dengan demikian tanaman dapat tumbuh dengan baik karena ada kesempatan untuk menyerap nutrisi (makanan) dari air dan juga proses fotosintesis tidak terganggu.

Laju pertumbuhan spesifik tiap minggu terus terjadi penurunan pada setiap perlakuan, hal ini dipengaruhi karena setelah ditanam, energi yang didapat oleh rumput laut digunakan untuk tumbuh, beradaptasi dan menyembuhkan luka. Dan pada minggu ke-3 dan ke-4 perbedaan penurunanya tidak terlalu jauh antar masing-masing perlakuan. Hal ini karena energi yang di dapatkan oleh rumput laut tidak lagi digunakan untuk tumbuh melainkan untuk menambah kadar karaginannya. Sehingga rumput laut yang akan dijadikan bibit kembali akan memiliki pertumbuhan yang optimal jika dipanen 
pada umur 4 minggu atau 30 hari setelah penanaman. Dari hasil laju pertumbuhan spesifik dan persentase pertumbuhan rumput laut hasil kultur jaringan terlihat bahwa bibit dengan berat 50 gr memiliki laju pertumbuhan lebih tinggi, sedangkan bibit dengan berat 125 gr memiliki laju pertumbuhan paling rendah. Hal tersebut dipengaruhi oleh persaingan antar rumput laut dalam menyerap cahaya matahari yang masuk ke perairan. Menurut Prihaningrum, dkk (2001), menyatakan bahwa semakin besar jumlah bibit dalam satu ikatan maka semakin tinggi kepadatannya sehingga persaingan untuk menyerap nutrisi dari perairan akan semakin tinggi. Namun akan membutuhkan energi yang lebih besar juga untuk pertumbuhannya.

Penurunan laju pertumbuhan spesifik pada bibit hasil kultur jaringan terus menurun disetiap minggunya. Laju pertumbuhan spesifik yang paling tinggi didapat pada berat bibit 50 gr dan terendah pada berat bibit 125 gr. Penurunan laju pertumbuhan ini sesuai dengan pendapat Yusnaini, $d k k$ (2000), yang menyatakan bahwa penurunan laju pertumbuhan spesifik diduga akibat cepatnya terjadi kejenuhan pada saat pembelahan sel. Rumput laut yang telah mengalami proses adaptasi kemudian mengalami fase pertumbuhan yang cepat dan kemudian terjadi penurunan kemampuan pertumbuhan sel yang dimana menyebabkan kemampuan pertumbuhannya menjadi lambat dan menurun.

Pada hama dan penyakit yang diamati pada bibit hasil kultur jaringan hampir tidak terdapat hama dan penyakit. Hal ini karena bibit hasil kultur jaringan benar-benar steril dan terbebas dari serangan penyakit. Hal ini sesuai dengan pendapat Marisca (2013), yang menyatakan bahwa Kultur jaringan merupakan salah satu cara atau teknik untuk memperbanyak tanaman secara aseptik yang ditujukan kepada bagian sel atau jaringan dari suatu tanaman. Hal ini dimaksudkan agar sel atau jaringan dari suatu tanaman tersebut bergenerasi sendiri sehingga tanaman tersebut serupa dengan tanaman induknya. Ciri teknik kultur jaringan adalah kondisi kultur yang aseptis, penggunaan media kultur buatan dengan kandungan nutrisi lengkap dan kondisi lingkungan yang sesuai. Lingkungan yang sesuai dapat dipengaruhi dengan menentukan media tumbuh yang sesuai dan menempatkan pada kondisi yang terkendali berkaitan dengan intensitas dan periodesitas, cahaya, temperatur dan kelembaban serta keharusan sterilisasi.

Hasil pengukuran kualitas air sesuai dengan tingkat kemampuan rumput laut untuk mentoleransi keadaan dan perubahan lingkungan hidupnya. Purwanto, dkk (2008) menyatakan bahwa Kappaphycus alvarezii memerlukan sinar matahari untuk fotosintesis, oleh karena itu rumput laut jenis ini hanya mungkin hidup pada lapisan fotik, yaitu kedalaman sejauh sinar matahari masih mampu mencapainya. Kappaphycus alvarezii tumbuh di rataan terumbu karang dangkal sampai kedalaman $6 \mathrm{~m}$, melekat di batu karang, cangkang kerang, dan benda keras lainnya. Faktor yang sangat berpengaruh pada pertumbuhan jenis ini yaitu cukup arus dengan salinitas (kadar garam) yang stabil yaitu berkisar 28-34 per mil, suhu berkisar antara $20-28^{\circ} \mathrm{C}$ dengan fluktuasi harian maksimum $4^{\circ} \mathrm{C}$. Oleh karena itu, rumput laut jenis ini akan hidup baik bila jauh dari muara sungai. Jenis ini telah dibudidayakan dengan cara diikat pada tali sehingga tidak perlu melekat pada substrat karang atau benda lainnya.

\section{Kesimpulan}

Perbedaan berat bibit rumput laut Kappaphycus alvarezii berpengaruh terhadap pertumbuhan mutlak dan laju pertumbuhan spesifik. Laju pertumbuhan rumput laut paling tinggi didapat pada berat 
bibit 50 gr. Hasil persentase pertambahan beratnya yaitu berat 50 gr mencapai $622 \%$ atau 6,22 kali dari bobot awal tubuhnya sedangkan pada berat 125 gr hanya mencapai $407 \%$ atau 4,07 kali dari bobot awal tubuhnya.

\section{Daftar Pustaka}

Anas, dkk. (2018). Gracilaria verrucosa growth rate cultivated using bottom off method. AIP Conference Proceeding. Malang, International Conference on Biologi and Applied Science.

Aslan, L. M. (1998). Budidaya rumput laut (Edisi Revisi). Yogyakarta, Penerbit Kanisius.

Baweja, P., ett all. Biology of seaweed. United Stated., University of Southern Maine.

Bhakuni, D.S. and D.S. Ranat. (2005). Bioactive marine natural product. New Delhi, India, Anamaya Publishers.

Cokrowati, N. (2013). Buku ajar teknologi budidaya rumput laut. Universitas Mataram, Program Studi Budidaya Perairan.

Dawes, C. J. (1994). Laboratory and field growth studies of commercial strains of Eucheuma denticulatum and Kappaphycus alvarezii. Philippines, J Appl, Phycol Inc.

Ditjenkan Budidaya. (2004). Budidaya rumput laut prosiding pertemuan teknis budidaya. Jakarta, Kementerian Kelautan dan Perikanan.

Doty, M.S. (1987). The production and uses of Eucheuma in case studies ofseven commercial seaweed reosurces. Santelices (Eds), FAO Fisheries Technical Paper.

Lobban,C.and Paul, J.H. (2000). Seaweed Ecology and Physiology. Newyork, Cambridge University.
Marisca, N. (2013). Aklimatisasi rumput laut Kappaphycus alvarezii hasil kultur jaringan dengan kepadatan yang berbeda dalam akuarium di rumah kaca. Skripsi. Teknologi Dan Manajemen Perikanan Budidaya Fakultas Perikanan Dan Ilmu Kelautan Institut Pertanian Bogor. Bogor.

Maryunus, R. dan Rusman. (2017). Performansi pertumbuhan bibit kuljar rumput laut Kotoni (Kappaphycus alvarezii) di perairan Teluk Vir Bangir Kota Tual. Prosiding. Surabaya, Indo Aqua-Asia Pasific Aquaculture.

Purwanto. (2008). Rumput Laut. Jakarta, Penebar Swadaya.

Sarifin. (2012). Petunjuk teknis budidaya rumput laut. Lombok, Balai Budidaya laut Lombok. 